\title{
Leaf morphology and anatomy of genus Androcymbium (Colchicaceae) in Southwest Africa
}

\author{
N. Membrives ${ }^{1}$, J. Pedrola-Monfort $^{2}$ \& J. Caujapé-Castells ${ }^{3}$
}

\begin{abstract}
Membrives, N., J. Pedrola-Monfort \& J. Caujapé-Castells (2003). Leaf morphology and anatomy of genus Androcymbium (Colchicaceae) in Southwest Africa. Collect. Bot. (Barcelona) 26: 83-99.

Morphological and anatomical leaf studies were made in 32 populations belonging to 17 taxa of the genus Androcymbium in Southwest Africa. The morphological characters studied were corm and tunic characteristics, and number, distribution, shape, size, section, and color of leaves and bracts. The micromorphological characters were the leaf indument on both surface and margin, shape and size of epidermic cells, type and amount of stomata. Finally, the anatomical characters were mesophyll cell types, epidermic cell sizes, cellular wall types, size of central epidermic cells related to the other epidermic cells, and amount of idioblasts. The results showed a great heterogeneity in almost all characters analyzed. However, macromorphological characteristics related to color and shape of leaves and bracts in the genus Androcymbium could be used as indicators of taxonomic affinities among species. Conversely, the micromorphological and anatomical characteristics studied showed a great variation of types that does not agree with the interspecific relationships established from morphological, allozymatic or cpDNA RFLP data in other research carried out within the genus.
\end{abstract}

Key words: Androcymbium, Colchicaceae, morphology, anatomy.

\section{Resumen}

Membrives, N., J. Pedrola-Monfort \& J. CAujapé-CASTells (2003). Morfología y anatomía del género Androcymbium (Colchicaceae) en Suráfrica Occidental. Collect. Bot. (Barcelona) 26: 83-99.

Se realizaron estudios morfológicos y anatómicos de las partes vegetativas en 32 poblaciones pertenecientes a 17 taxones del género Androcymbium en Suráfrica Occidental. Los caracteres morfológicos estudiados fueron las características del cormo y de las túnicas, y número, distribución, forma, tamaño, sección, y color de las hojas y brácteas. Los caracteres micromorfológicos estudiados fueron el indumento en la superficie y margen de la hoja, forma y tamaño de las células epidérmicas, y tipo y cantidad de estomas. Finalmente, los caracteres anatómicos fueron el tipo de células del mesofilo, tamaño de las células epidérmicas, tipo de pared celular, tamaño de las células epidérmicas centrales comparado con el resto de células de la lámina y cantidad de idioblastos. Los resultados mostraron una gran heterogeneidad en la mayoría de los caracteres analizados. A pesar de ello, algunas características macromorfológicas relacionadas con el color y forma de las hojas y brácteas en el género Androcymbium, podrían ser utilizadas como indicadores taxonómicos de afinidades entre especies. Contrariamente, las características micromorfológicas y anatómicas estudiadas mostraron una gran variedad de formas que no se ajustan a las relaciones entre especies establecidas previamente a partir de datos de morfología, aloenzimas o RFLPs del cpDNA.

\footnotetext{
${ }^{1}$ Jardí Botànic de Barcelona, c/ Font i Quer s/n., 08038 Barcelona, Spain. E-mail: nuriamem@telefonica.net

${ }^{2}$ Estació Internacional de Biologia Mediterrània-Jardí Botànic Marimurtra, Passeig Karl Faust 10, 17300 - Blanes, Girona, Apdo. de correos 112, Spain.

${ }^{3}$ Jardín Botánico Canario Viera y Clavijo, Apdo 14 de Tafira Alta, 35017- Las Palmas de Gran Canaria, Spain.
} 


\section{INTRODUCTION}

The species of Androcymbium Willd. (Colchicaceae) are geophytes with an annual vegetative cycle that spend the unfavorable period buried as tunicate corms. The genus includes about 40 species (ARNOLD \& WeTt, 1993; Müller-Doblies \& MüLlER-Doblies, 1984, 1998; PEDROLA-MONFORT et al., 1999a, 1999b, in press.) with a disjunct distribution in Africa (fig. 1A).

The six species in North Africa are distributed throughout the Mediterranean basin and the Canary Islands. Despite their close morphological similarity, MATEU-ANDRÉS et al. (1996) argued that several morphological leaf characters are useful for inter-specific differentiation. Qualitative (size, shape, color, and number of leaves) and anatomical characters (mesophyll cell types, epidermic cell size, thickness of cell wall, and central epidermic cell size related to the rest of the lamina) were particularly discriminative.

The rest of the species in the genus are distributed in South Africa, mainly in the Western region. These species display much higher variability levels than their Northern African congeners at the morphological (BAKER, 1974; Krause, 1920; MÜLler-Doblies \& MüLlerDoblies, 1998; Membrives, 2000), pollinic (Martín et al., 1993; Membrives, 2000; MEmbrives et al., 2002), karyological (Margelí et al., 1998; MontSERrat et al., 2002), allozymatic (MEmBRIVES et al., 2001) and cpDNA (CAUJAPÉ-CASTELlS et al., 1999) levels.

The main objective of this work is to evaluate the variation in leaf and bract morphological and anatomical features of a comprehensive representation of taxa of the genus Androcymbium distributed in Southwest Africa (fig. 1B).

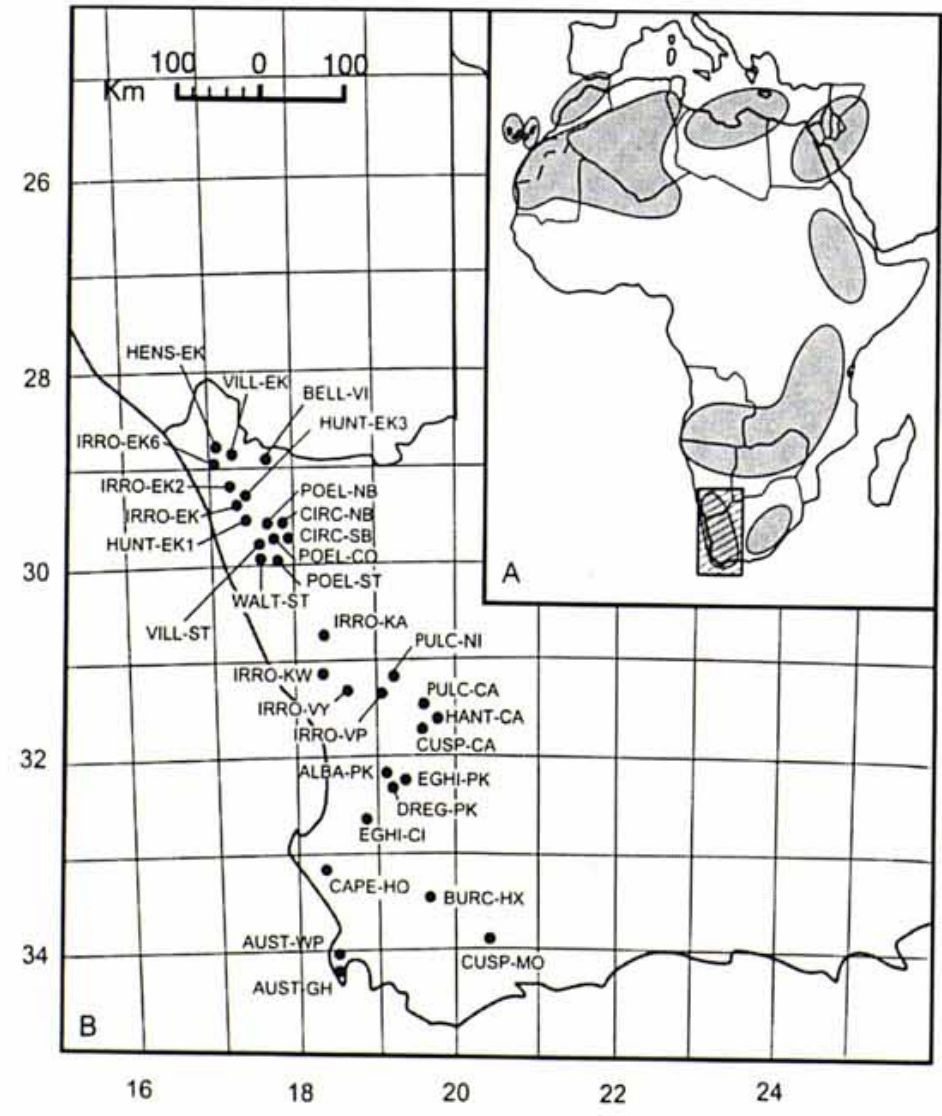

Figure 1.- A. Geographical distribution of genus Androcymbium. B. Distribution of the Southwestern African populations studied. Abbreviations of populations are described in Table 1. 


\section{MATERIAL AND METHODS}

We sampled 32 populations belonging to 17 taxa of the genus Androcymbium (Table 1). These samples are currently in cultivation at the greenhouses of the "Estació Internacional de Biologia Mediterrània-Jardí Botànic Marimurtra". Quantitative and qualitative morphological data were obtained from the observation of adult plants in cultivation measured after the anthesis. The terminology used for the morphological descriptions of leaves and bracts follows HeYwOOD (1978). Micromorphological and anatomical characters were obtained from samples of the central part of the lamina of the first leaf.

\section{Macromorphological characters}

We studied corm morphology, tunic characteristics and several vegetative characters in leaves and bracts (number, distribution, shape, size, section, and color). Observations were made from material in cultivation and from herbarium sheets of specimens collected in the field.

\section{Micromorphological characters}

Leaves were heated in chloral hydrate to separate the cuticle and then dyed with saphranine. The studied characters were the indument both on the surface and the margin of the leaf, the shape and size of epidermic cells, and the type and amount of stomata. The stomatic indices (STIs) are the quotient (expressed in percentage) between the number of stomatic cells and the number of total cells (stomata plus epidermic cells) in a restricted leaf area. Problems with manipulation of leaves in A. henssenianum and A. huntleyi did not allow us to obtain this kind of information for these species.

\section{Anatomical characters}

Leaves were fixed in Carnoy's solution (JOHANSEN, 1970), and cut using a scalpel blade and a binocular magnifying glass. The anatomical characters studied were mesophyll cell types, epidermic cell sizes, cellular wall types, size of central epidermic cells relative to the other epidermic cells, and amount of idioblasts.

\section{RESULTS}

\section{Corm}

The corm is rounded in most of the species studied, and dorsiventrally compressed in A. bellum, A. poeltianum, and A. walteri. The corm is wrapped by a leaf (called cataphyll) that becomes a tunic in the next cycle, with either a papery texture (in A. austrocapense and other Southeast African species like A. decipiens, A. longipes, and A. natalense) or a coriaceous texture (the remaining species studied). The tunic surface is generally smooth, except for A. bellum, A. poeltianum, and A. walteri, where it is ragged. A basal elongation of the corm and tunics (the crest) is a diagnostic characteristic of the genus (fig. 2A). This feature is largely developed in A. cuspidatum (fig. 2B), and extends widely over the corm faces in A. bellum, A. poeltianum, and A. walteri (fig. 2C).

\section{Morphology and leaf distribution}

All studied species showed three leaves, rarely four (only in A. austrocapense, A. irroratum and $A$. walteri). The leaves are alternate (fig. $3 \mathrm{~A}$ ) and make up close nodes that generally form a basal rosette. Androcymbium bellum, A. circinatum, A. dregei and A. walteri develop an epigeous stem in cultivation. This variability in stem length is probably due to insufficient sunlight in the greenhouses, and was also described previously in $A$. dregei (MülLer-Doblies \& Müller-Doblies, 1984). In almost all species, the leaves are 
Table 1.- Populations of Androcymbium analysed. Population, Code and Locality.

A. albanense Schönland subsp. clanwilliamense Pedrola, Membrives \& J. M. Monts., ALBAPK, 3219AA. Wuppertal: Clanwilliam to Wuppertal road, km 10.

A. austrocapense U. Müll.-Doblies \& D. Müll.-Doblies, AUST-GH, 3418AC. Simonstown: Cape of Good Hope.

A. austrocapense U. Müll.-Doblies \& D. Müll.-Doblies, AUST-WP, 3418AD. Simonstown: Whale's Point, Cape Point Reserve.

A. bellum Schltr. \& K. Krause, BELL-VI, 2817DC. Vioolsdrift: Steinkopf to Vioolsdrift road, $\mathrm{km} 40$.

A. burchellii Baker subsp. burchellii, BURC-HX, 3319BC. Worcester: from Worcester to Towsrivier road.

A. burchellii Baker subsp. pulchrum Pedrola, Membrives, J. M. Monts. \& Caujapé, PULC-CA, 3119DA. Calvinia: Calvinia to Ceres road, $7 \mathrm{~km}$ turnoff to Kreitzberg.

A. burchellii Baker subsp. pulchrum Pedrola, Membrives, J. M. Monts. \& Caujapé, PULC-NI, 3118AA. Calvinia: Wild flower reserve of Nieuwoudtville.

A. capense (L.) K.Krause, CAPE-HO, 3318AB. Cape Town: Malmesbury to Hopefield road, $\mathrm{km} 49$.

A. circinatum Baker, CIRC-NB, 2917DB. Springbok: Springbok to Nababeep road, $100 \mathrm{~m}$. A. circinatum Baker, CIRC-SB, 2917DB. Springbok: $3 \mathrm{~km}$ W of Springbok.

A. cuspidatum Baker, CUSP-CA, 3119DA. Calvinia: Calvinia to Ceres road, $7 \mathrm{~km}$ turnoff to Kreitzberg.

A. cuspidatum Baker, CUSP-MO, 3320CD. Montagu: Near Montagu-Badskloof, W of the Gorgo.

A. dregei C.Presl, DREG-PK, 3219AA Wuppertal: Clanwilliam to Wuppertal road, km 28. A. eghimocymbion U. Müll.-Doblies \& D. Müll.-Doblies, EGHI-CI, 3218DB. Clanwilliam: Piketberg to Citrusdal Pass.

A. eghimocymbion U. Müll.-Doblies \& D. Müll.-Doblies, EGHI-PK, 3219AA. Wuppertal: Clanwilliam to Wuppertal road, $\mathrm{km} 28$.

A. hantamense Schinz, HANT-CA, 3119DA. Calvinia: Calvinia to Ceres road, $7 \mathrm{~km}$ turnoff to Kreitzberg.

A. henssenianum U. Müll.-Doblies \& D. Müll.-Doblies, HENS-EK, 2817CC. Vioolsdrift: Eksteenfontein to Modderfontein road.

A. huntleyi Pedrola, Membrives, J. M. Monts. \& Caujapé, HUNT-EK1, 2917AD. Springbok: Springbok to Port Nolloth road, $14 \mathrm{~km}$ to Eksteenfontein.

A. huntleyi Pedrola, Membrives, J. M. Monts. \& Caujapé, HUNT-EK3, 2917AD. Springbok: Springbok to Port Nolloth road, $20 \mathrm{~km}$ to Eksteenfontein.

A. irroratum Schltr. \& K. Krause, IRRO-EK, 2917AD. Springbok: Springbok to Port Nolloth road, $6 \mathrm{~km}$ to Eksteenfontein.

A. irroratum Schltr. \& K. Krause, IRRO-EK2, 2917AD. Springbok: Springbok to Port Nolloth, $15 \mathrm{~km}$ to Eksteenfontein.

A. irroratum Schltr. \& K. Krause, IRRO-EK6, 2817CC. Vioolsdrift: Eksteenfontein to Modderfontein road.

A. irroratum Schltr. \& K. Krause, IRRO-KA, 3018CB. Kamiesberg: Bitterfontein to Kliprand road. A. irroratum Schltr. \& K. Krause, IRRO-KW, 3118BC. Vanrhynsdorp: Vredental to Koekenaap road, $100 \mathrm{~m}$ to train station.

A. irroratum Schltr. \& K. Krause, IRRO-VP, 3119AC. Calvinia: Vanrhynspass.

A. irroratum Schltr. \& K. Krause, IRRO-VY, 3118AD.Vanrhynsdorp: Vrendendal to Vanrhynsdorp road.

A. poeltianum U. Müll.-Doblies \& D. Müll.-Doblies, POEL-CO, 2917DB. Springbok: Springbok to Concordia road.

A. poeltianum U. Müll.-Doblies \& D. Müll.-Doblies, POEL-NB, 2917DB. Springbok: Springbok to Nababeep road, $100 \mathrm{~m}$. 
Table 1. Cont.

A. poeltianum U. Müll.-Doblies \& D. Müll.-Doblies, POEL-ST, 2917DC. Springbok: Steinkopf to Springbok road, $5 \mathrm{~km}$.

A. villosum U. Müll.-Doblies \& D. Müll.-Doblies, VILL-EK, 2817CC. Vioolsdrift: $1 \mathrm{~km} \mathrm{~S}$ of Eksteenfontein

A. villosum U. Müll.-Doblies \& D. Müll.-Doblies, VILL-ST, 2917BC. Springbok: $3 \mathrm{~km} \mathrm{~S}$ of Steinkopf.

A. walteri Pedrola, Membrives \& J. M. Monts., WALT-ST, 2917DC. Springbok: Steinkopf to Springbok road, $5 \mathrm{~km}$.
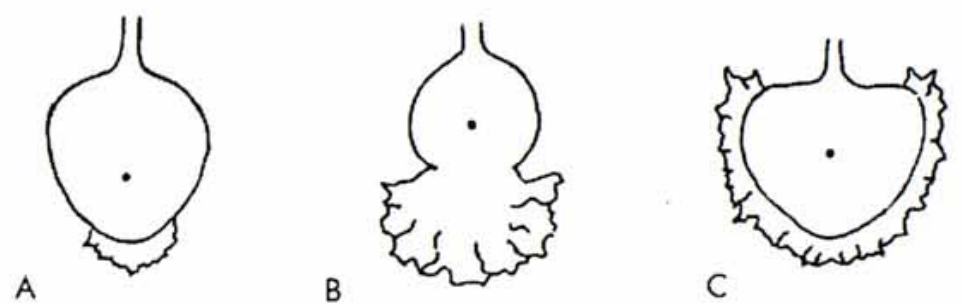

Figure 2.- Shape of the corm crest in Androcymbium. A. Basal crest. B. Basal crest largely developed (A. cuspidatum). C. Basal crest growing by the corm faces (A. bellum, $A$. poeltianum and $A$. walteri).
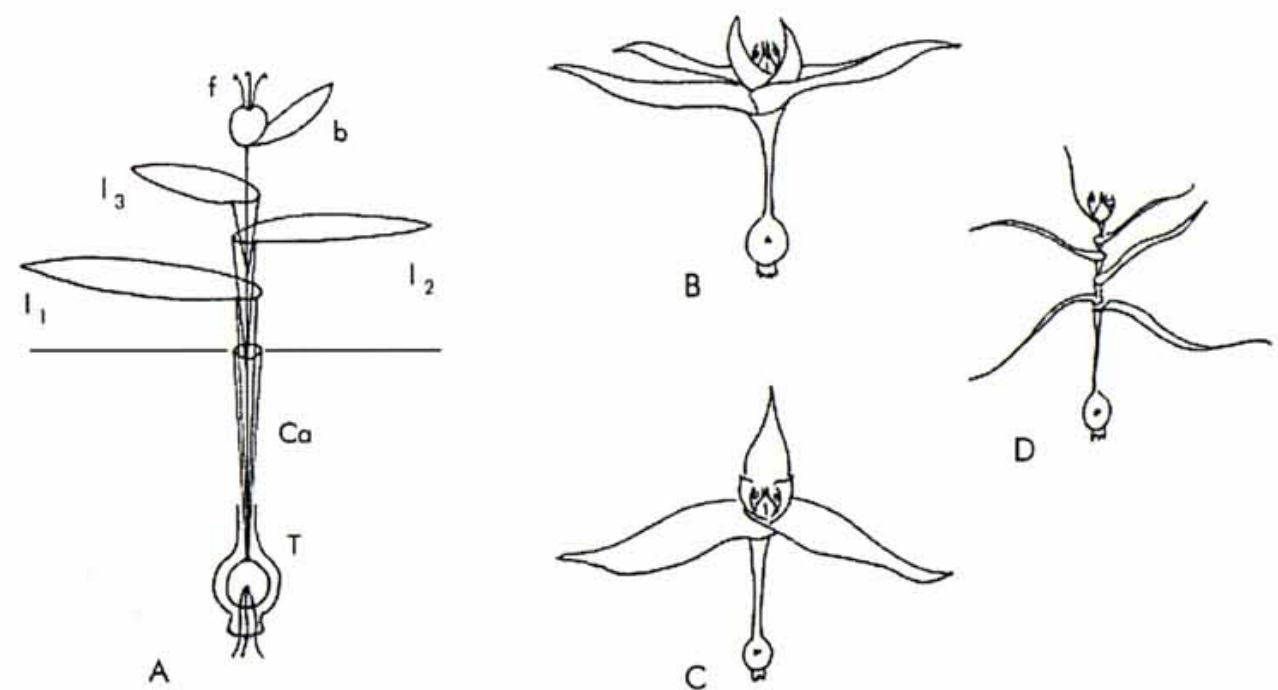

Figure 3.- A. General plant structure in Androcymbium. B. Distichous distribution. C. Tristichous distribution. D. Helicoidal distribution $(\mathrm{T}=$ tunic; $\mathrm{Ca}=$ cataphyll; $\mathrm{l}(\mathrm{x})=$ leaves; $b=$ bract, $f=$ flower $)$.

distributed distichously (fig. 3B), like in most genera of the Liliales (DAHLGREN, 1985). However, the distribution of leaves in A. cuspidatum is either tristichous (fig. $3 \mathrm{C}$ ) or distichous with the first leaf in a transversal position. Leaf distribution around the stem is helicoidal in A. dregei (fig. 3D) and in the Northern African circumscription of the genus (Pedrola-Monfort, 1993; Mateu-AndrÉs et al., 1996). 
The leaves are generally linear-lanceolate. However, they are acicular in A. dregei and A. henssenianum, and ovate-lanceolate in A. burchellii subsp. burchellii, A. burchellii subsp. pulchrum, A. cuspidatum, and A. irroratum. The biometric characteristics of the first leaf are described in Table 2a. The largest leaves are those of $A$. austrocapense (mean value of $23.8 \mathrm{~cm}$ ) and the shortest those of $A$. cuspidatum (mean value of $4.1 \mathrm{~cm}$ ). The narrowest leaves belong to $A$. dregei and $A$. henssenianum (mean values of 0.1 and $0.2 \mathrm{~cm}$, respectively), and the widest belong to A. burchellii subsp. burchellii, A. burchellii subsp. pulchrum, and $A$. capense (mean values of $2.3,2.9$ and $2.3 \mathrm{~cm}$, respectively). All species studied showed a flat leaf apex, except for $A$. circinatum, $A$. henssenianum, and $A$. villosum, which showed a circinate apex.

Two general types of leaf section were observed (figs. 4, 5 and 6): flat with a shallow depression in the region of the central nerve (A. burchellii subsp. burchellii, $A$. burchellii subsp. pulchrum, $A$. capense, A. cuspidatum, A. hantamense, A. irroratum, $A$. poeltianum and $A$. walteri), and V-shaped (A. albanense subsp. clanwilliamense, $A$. austrocapense, A. bellum, A. dregei and A. eghimocymbion). Androcymbium circinatum, A. henssenianum, A. huntleyi and $A$. villosum showed an intermediate leaf section (fig. $5 \mathrm{~F}$; fig. $6 \mathrm{~F}, 6 \mathrm{~J}, 6 \mathrm{~L})$.

The leaves were either bright green (A. albanense subsp. clanwilliamense, A. austrocapense, A. burchellii subsp. burchellii, A. burchellii subsp. pulchrum, A. capense, A. cuspidatum, A. eghimocymbion and A. irroratum) or green-glaucous (A. bellum, A. circinatum, A. dregei, A. hantamense, A. henssenianum, A. huntleyi, A. poeltianum, A. villosum and A. walteri).

Table 2a.- Macromorphological leaf characters in Androcymbium. Shape: $\mathrm{A}=\mathrm{Acicular}$, $\mathrm{L}=\mathrm{Linear}$; $\mathrm{LA}=\mathrm{Lanceolate}$; $\mathrm{OV}=\mathrm{Ov}$ ate. Measures are expressed in $\mathrm{cm}$. Color: $\mathrm{GL}=\mathrm{Glauc} ; \mathrm{GR}=\mathrm{Green}$. * $=$ presence of red spots.

\begin{tabular}{|c|c|c|c|c|c|c|}
\hline \multirow[b]{2}{*}{ Taxon } & \multicolumn{4}{|c|}{ Leaves } & \multirow{2}{*}{\multicolumn{2}{|c|}{ Section Colour }} \\
\hline & Shape & Length & Width & L/W & & \\
\hline $\begin{array}{l}\text { A. albanense subsp. } \\
\text { clanwilliamense }\end{array}$ & L-LA & $(10.0) 13.3(15.5)$ & $(0.7) 0.9(1.1)$ & 14.8 & V & GR \\
\hline A. austrocapense & L-LA & $(13.5) 23.8(35.6)$ & $(0.5) 1.1(2.1)$ & 23.0 & V & GR \\
\hline A. bellum & $\mathrm{L}$ & $(11.0) 13.0(15.0)$ & $(0.3) 0.4(0.6)$ & 35.5 & V & GL \\
\hline $\begin{array}{c}\text { A. burchellii subsp. } \\
\text { burchellii }\end{array}$ & OV-LA & $(12.5) 15.9(21.0)$ & $(1.6) 2.3(3.7)$ & 7.4 & $\mathrm{Pl}$ & GR \\
\hline $\begin{array}{c}\text { A. burchellii subsp. } \\
\text { pulchrum }\end{array}$ & OV-LA & (7.0)13.0(23.0) & $(1.4) 2.9(5.6)$ & 5.2 & $\mathrm{Pl}$ & GR \\
\hline A. capense & LA & $(14.0) 15.3(17.5)$ & $(1.7) 2.3(3.0)$ & 6.8 & $\mathrm{Pl}$ & GR \\
\hline A. circinatum & L-LA & $(14.0) 19.3(24.5)$ & $(0.5) 0.9(1.3)$ & 24.3 & Pl-V & GL* \\
\hline A. cuspidatum & OV-LA & $(2.2) 4.1(5.5)$ & $(1.1) 1.7(2.2)$ & 2.5 & $\mathrm{Pl}$ & GR \\
\hline A. dregei & A & $(6.5) 7.9(9.2)$ & $(0.1) 0.1(0.2)$ & 71.3 & V & GL \\
\hline A. eghimocymbion & L-LA & $(13.7) 21.6(27.0)$ & $(0.4) 0.7(1.0)$ & 35.4 & V & GR \\
\hline A. hantamense & LA & $(11.0) 15.2(20.5)$ & $(1.3) 1.9(2.7)$ & 8.5 & $\mathrm{Pl}$ & GL \\
\hline A. henssenianum & A & $(8.5) 15.0(21.0)$ & $(0.2) 0.2(0.2)$ & 84.0 & Pl-V & GL \\
\hline A. huntleyi & L-LA & $(7.0) 8.1(9.2)$ & $(0.7) 1.0(1.2)$ & 8.8 & $\mathrm{Pl}-\mathrm{V}$ & GL \\
\hline A. irroratum & OV-LA & $(5.0) 11.4(23.5)$ & $(0.5) 1.41(3.2)$ & 9.3 & $\mathrm{Pl}$ & GR \\
\hline A. poeltianum & L-LA & $(9.0) 12.4(15.5)$ & $(0.4) 0.7(1.3)$ & 19.9 & $\mathrm{Pl}$ & GL \\
\hline A. villosum & L-LA & $(12.0) 13.4(16.5)$ & $(0.7) 0.9(1.0)$ & 15.8 & $\mathrm{Pl}-\mathrm{V}$ & GL \\
\hline A. walteri & L-LA & $(11.0) 16.9(21.5)$ & $(0.5) 1.0(1.4)$ & 18.3 & $\mathrm{Pl}$ & GL \\
\hline
\end{tabular}



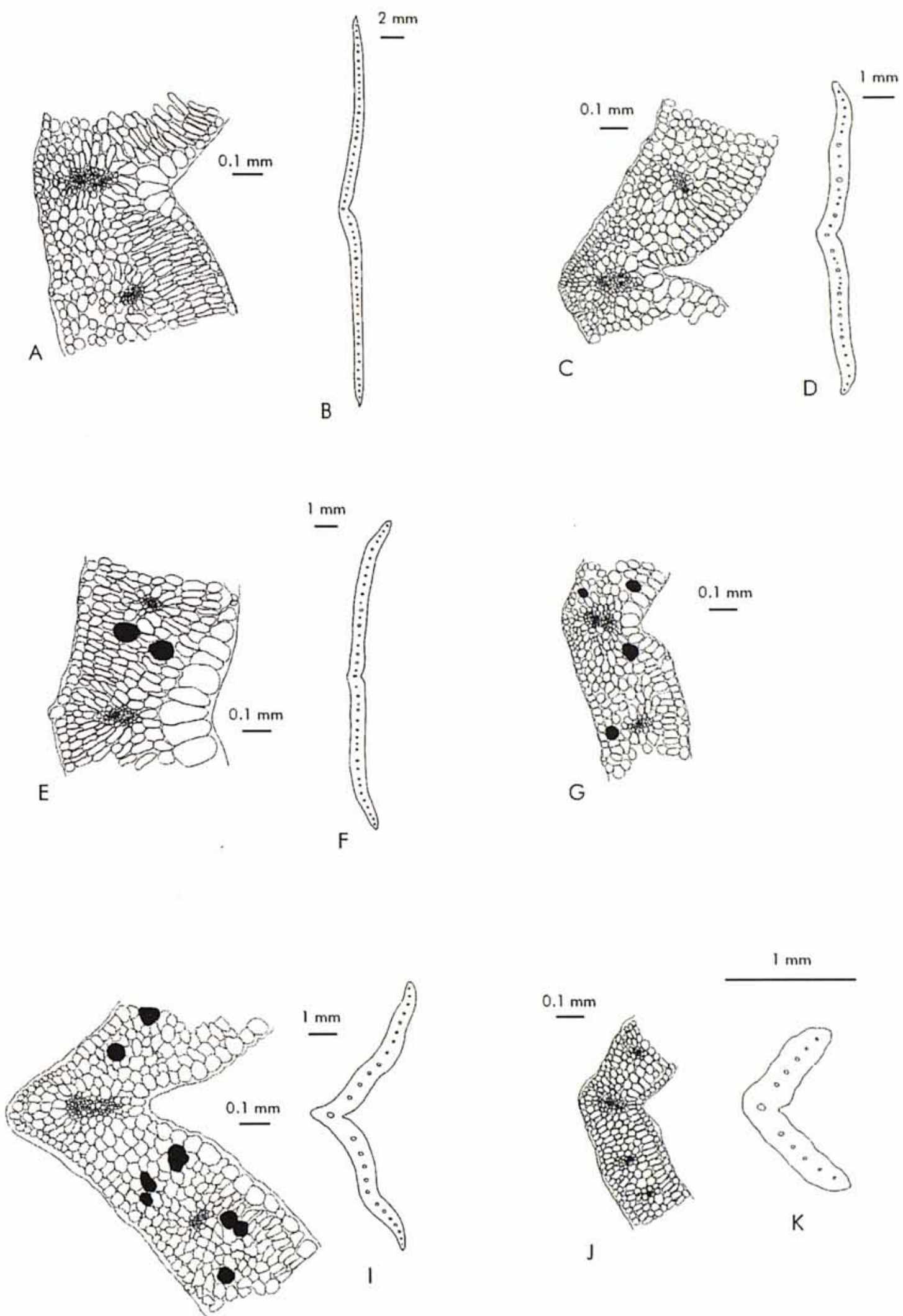

$\mathrm{H}$

Figure 4.- Mesophyll with differentiated cells. Section structure: A. A. burchellii subsp. burchellii. C. A. irroratum. E. A. hantamense. G. A. capense. H. A. austrocapense. J. A. dregei. Section: B. A. burchellii subsp. burchellii. D. A. irroratum. F. A. hantamense. I. A. austrocapense. K. A. dregei. Black circles in structure correspond to idioblasts. White circles in sections correspond to vascular vessels. 

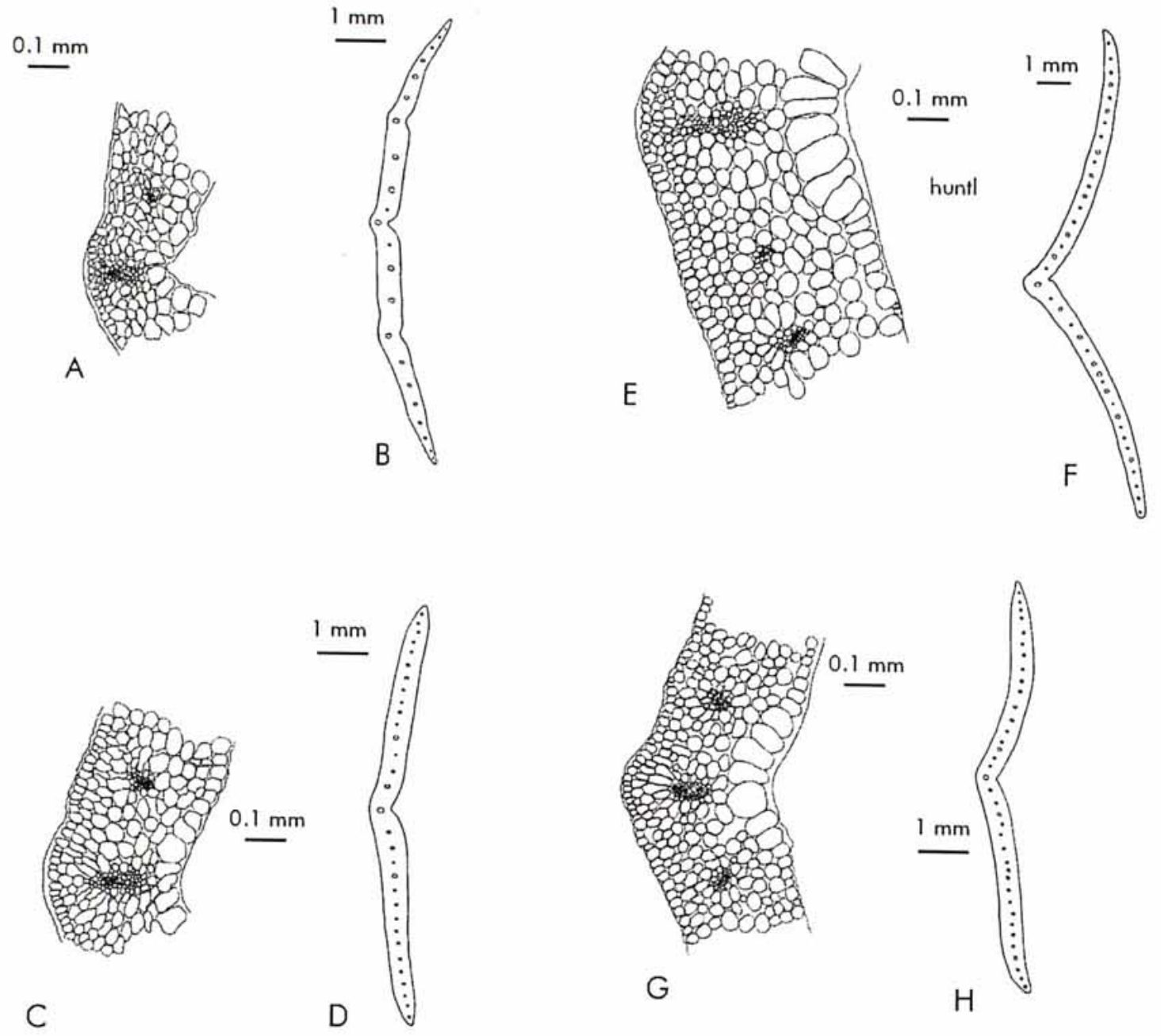

Figura 5.- Mesophyll with undifferentiated cells. Section structure: A. A. cuspidatum. C. A. poeltianum. E. A. huntleyi. G: A. walteri. Section: B. A. cuspidatum. D. A. poeltianum. F. A. huntleyi. H. A. walteri. Black circles in structure correspond to idioblasts. White circles in sections correspond to vascular vessels.

Androcymbium circinatum features red spots (approximately $1 \mathrm{~mm}$ in diameter) in leaves, bracts and tepal surface that appear just before flowering. This characteristic is shared by the new species A. comptonii U. Müll.-Doblies \& D. Müll.-Doblies (MÜLLER-DOBLIES \& MÜLLERDoBLIES, 1998). Both leaf faces in Androcymbium species are green, except in A. burchellii subsp. burchellii and in populations IRRO-KA and IRRO-VY of A. irroratum (abbreviations of populations are in Table 1), where they are purplish on the abaxial face.

The bracts usually differ from leaves in shape, color and texture. In most species, bracts were shorter and more rounded than leaves, and in some cases the color was different. Generally, the third leaf showed an intermediate shape between leaf and bract. Although most species of Androcymbium surveyed showed elliptic or deltoid bracts, exceptions like acicular (A. dregei), lanceolate (A. henssenianum and A. poeltianum), and orbicular (A. burchellii subsp. burchellii and A. burchellii subsp. pulchrum) do occur (Table $2 \mathrm{~b}$ ). The bract measurements are given in Table 2b. The largest bracts occur in A. burchellii subsp. pulchrum and $A$. hantamense (mean values of 7.4 and $7.7 \mathrm{~cm}$, respectively), and the shortest in A. albanense 


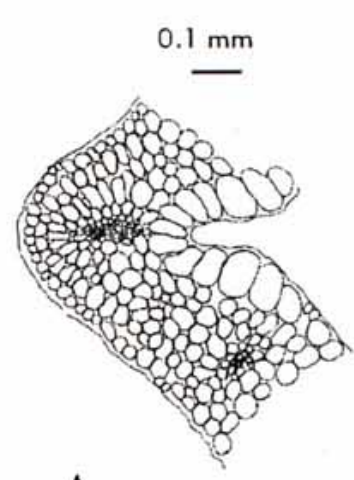

A
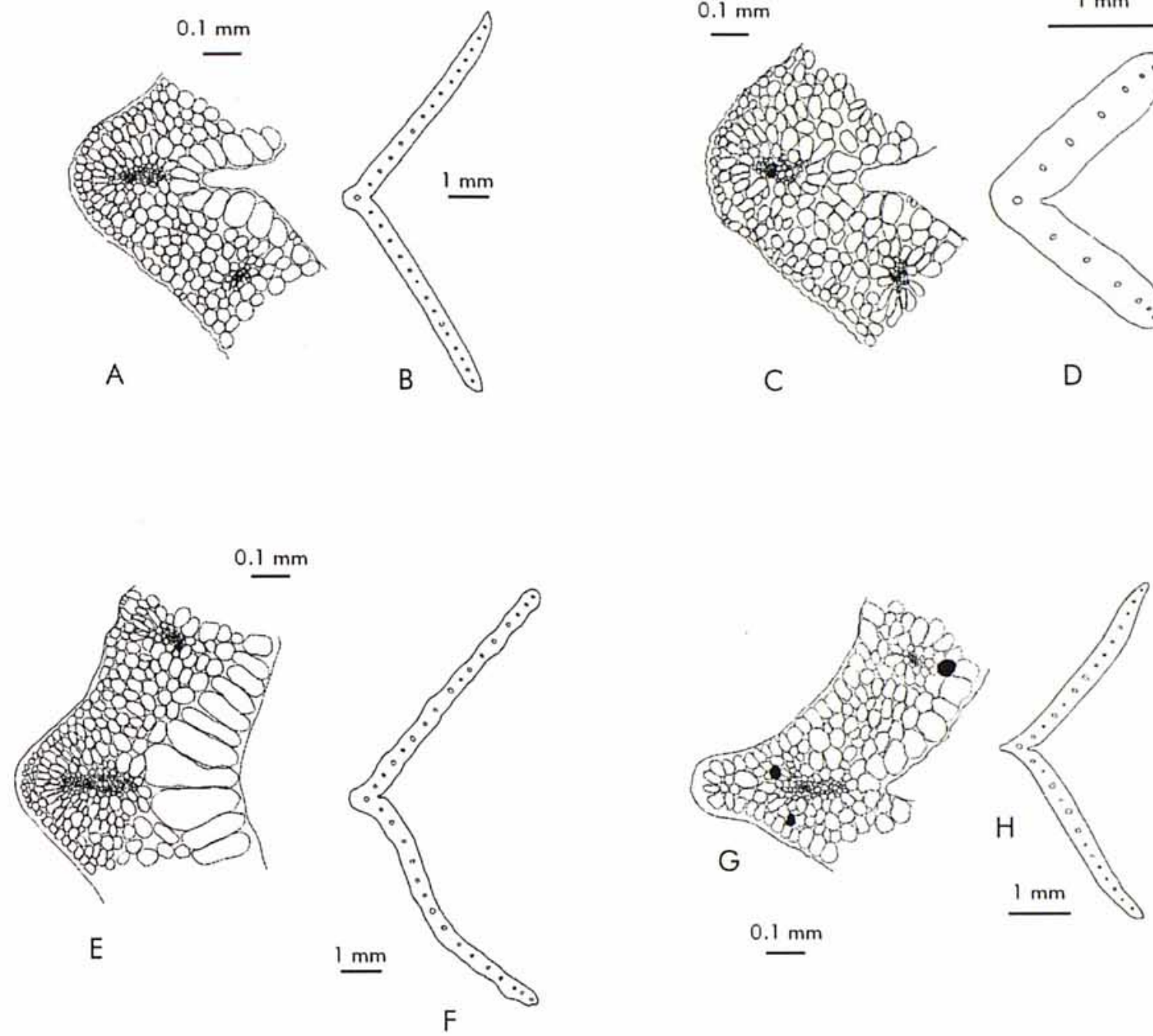

$\underline{0.1 \mathrm{~mm}}$

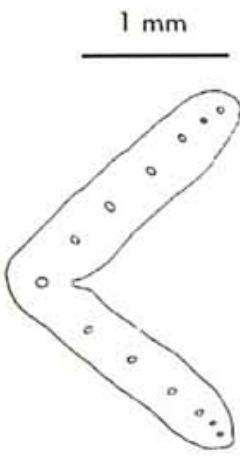

D

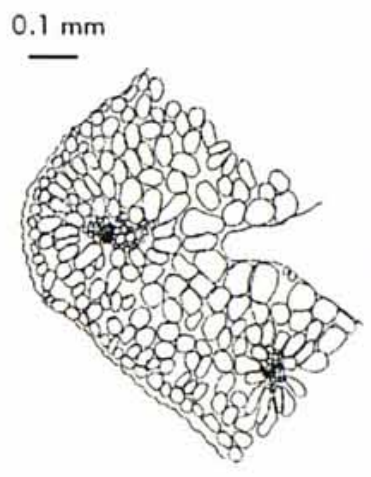

C

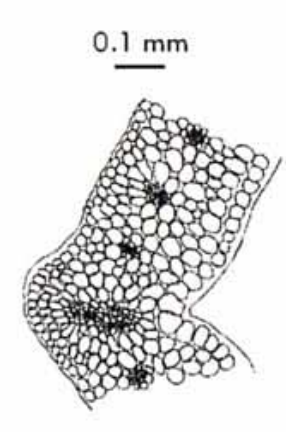

।

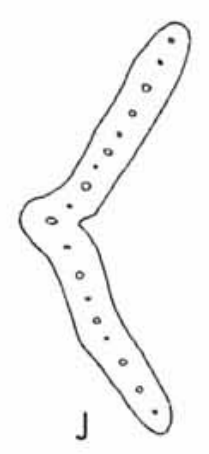

$1 \mathrm{~mm}$

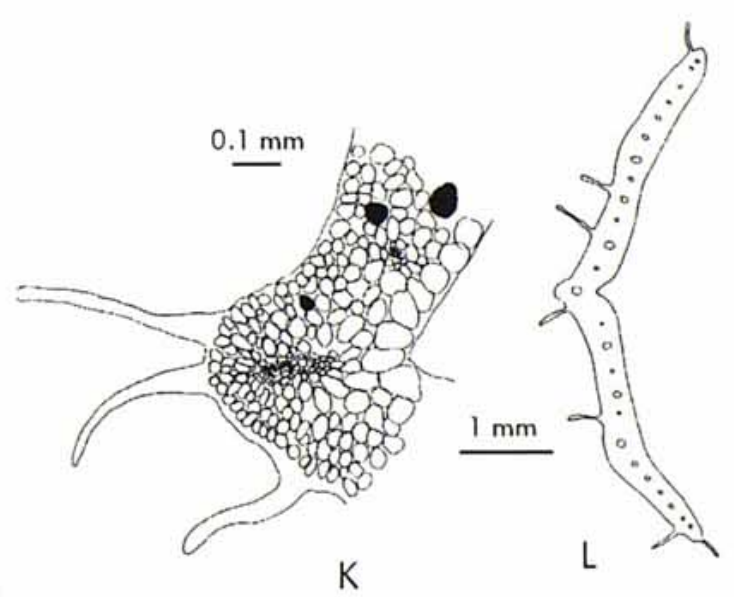

Figure 6.- Mesophyll with undifferentiated cells. Section structure: A. A. albanense subsp. clanwilliamense. C. A. bellum. E. A. circinatum. G. A. eghimocymbion. I. A. henssenianum. K. A. villosum. Section: B. A. albanense subsp. clanwilliamense. D. A bellum. F. A. circinatum. H. A. eghimocymbion. J. A. henssenianum. L. A. villosum. Black circles in structure correspond to idioblasts. White circles in sections correspond to vascular vessels. 
Table 2b.- Macromorphological bract characters in Androcymbium. Shape: A=Acicular; $\mathrm{DE}=$ Deltoid; $\mathrm{E}=\mathrm{Elliptic} ; \mathrm{LA}=$ Lanceolate; $\mathrm{OR}=$ Orbicular; $\mathrm{OV}=$ Ovate. Measures are expressed in $\mathrm{cm}$. Color: $\mathrm{WH}=\mathrm{White} ; \mathrm{GL}=\mathrm{Glauc} ; \mathrm{RE}=$ Reddish; $\mathrm{GR}=\mathrm{Green} .{ }^{*}=$ presence of red spots.

\begin{tabular}{|c|c|c|c|c|c|}
\hline \multirow[b]{2}{*}{ Taxon } & \multicolumn{5}{|c|}{ Bracts } \\
\hline & Shape & Length & Width & $\mathrm{L} / \mathrm{W}$ & Colour \\
\hline $\begin{array}{l}\text { A. albanense subsp. } \\
\text { clanwilliamense }\end{array}$ & DE & $(1.7) 2.7(4.0)$ & $(1.0) 1.7(2.0)$ & 1.71 & GR \\
\hline A. austrocapense & $\mathrm{DE}$ & $(2.5) 3.8(5.5)$ & $(2.5) 3.6(4.0)$ & 1.06 & GR \\
\hline A. bellum & $E$ & $(2.1) 3.3(6.2)$ & (1.5)2.0(2.9) & 1.67 & GL \\
\hline $\begin{array}{l}\text { A. burchellii subsp. } \\
\text { burchellii }\end{array}$ & OR & $(3.0) 3.9(5.0)$ & $(3.0) 4.3(5.2)$ & 0.93 & WH \\
\hline $\begin{array}{l}\text { A. burchellii subsp. } \\
\text { pulchrum }\end{array}$ & OV-OR & $(4.0) 7.4(12.5)$ & $(4.5) 6.3(9.0)$ & 1.20 & RE \\
\hline A. capense & E & $(4.0) 4.7(5.5)$ & (1.7)2.3(3.4) & 2.12 & GR-WH \\
\hline A. circinatum & E-DE & $(3.4) 4.5(6.2)$ & $(2.3) 3.0(4.4)$ & 1.51 & GL* \\
\hline A. cuspidatum & $\mathrm{DE}$ & $(2.4) 4.1(6.5)$ & $(1.1) 2.4(4.0)$ & 1.79 & GR \\
\hline A. dregei & A & $(2.5) 4.3(7.2)$ & $(0.15) 0.2(0.3)$ & 21.63 & GR \\
\hline A. eghimocymbion & DE & $(2.5) 4.1(8.0)$ & $(1.7) 2.8(4.0)$ & 1.48 & GR \\
\hline A. hantamense & E-LA & $(5.5) 7.7(11)$ & $(2.1) 3.8(6.0)$ & 2.16 & WH \\
\hline A. henssenianum & LA & $(3.4) 5.7(7.5)$ & $(1.3) 1.7(2.3)$ & 3.41 & GL \\
\hline A. huntleyi & E-DE & $(3.0) 3.1(3.2)$ & $(2.0) 2.1(2.2)$ & 1.48 & GL \\
\hline A. irroratum & E-DE & $(2.0) 3.8(5.0)$ & $(0.8) 2.2(3.5)$ & 1.77 & GR \\
\hline A. poeltianum & LA & $(2.4) 4.6(6.0)$ & $(1.1) 1.8(2.8)$ & 2.61 & GL \\
\hline A. villosum & E-DE & $(3.5) 5.5(7.5)$ & $(1.8) 2.7(4.0)$ & 2.05 & GL \\
\hline A. walteri & E-DE & $(2.7) 4.3(5.8)$ & $(2.1) 3.1(4.2)$ & 1.38 & GL \\
\hline
\end{tabular}

subsp. clanwilliamense (mean value of $2.7 \mathrm{~cm}$ ). The narrowest bracts belong to A. dregei (mean value of $0.2 \mathrm{~cm}$ ) and the widest to A. burchellii subsp. pulchrum (mean value of $6.3 \mathrm{~cm}$ ). On the whole, the bracts were green or green-glaucous, but they can also be white (A. capense, A. hantamense and A. burchellii subsp. burchellii) or reddish (A. burchellii subsp. pulchrum).

\section{Micromorphological characters of surface and leaf margin}

By and large, the indument of the leaf margin was either smooth or papillose (fig. 7A). Unicellular hairs (which can be simple or bifurcate) were observed in A. villosum (fig. 7B). Pluricellular hairs were short and sparse in A. burchellii subsp. burchellii and $A$. burchellii subsp. pulchrum (fig. 7C), and long and very frequent in $A$. capense and $A$. hantamense (fig. 7D). The leaf surface is glabrous in all of the studied species except in A. villosum, which shows unicellular hairs (simple or bifurcated) on the abaxial face of leaves and bracts.

The epidermis of the abaxial face of the leaves showed rectangular (fig. 8A), rhomboidal (fig. 8B) or polygonal cells (fig. 8C). Androcymbium burchellii subsp. burchellii and $A$. burchellii subsp. pulchrum had polygonal cells on both faces. This kind of cell was only observed on the abaxial face in A. hantamense and A. irroratum (Table 3). The anticlinal walls of the epidermic cells were straight, except for those of A. cuspidatum, which were curved (fig. 8D). The longest cells in the adaxial face belonged to A. eghimocymbion, and 

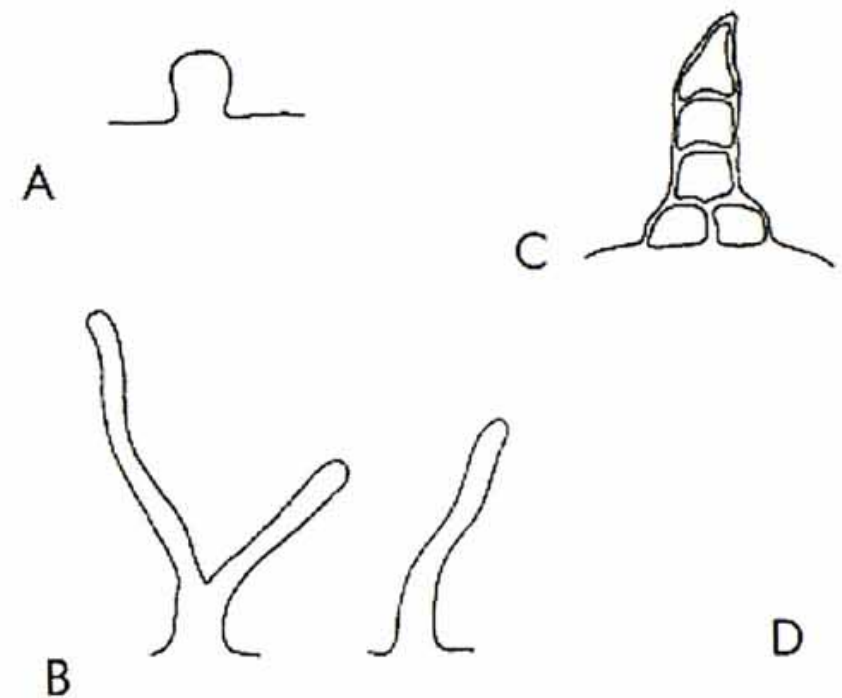

Figure 7.- Indument in leaf margin. A. Papillose. B. Unicellular, simple and bifurcate hairs (A. villosum). C. Pluricellular short hairs. D. Pluricellular long hairs.
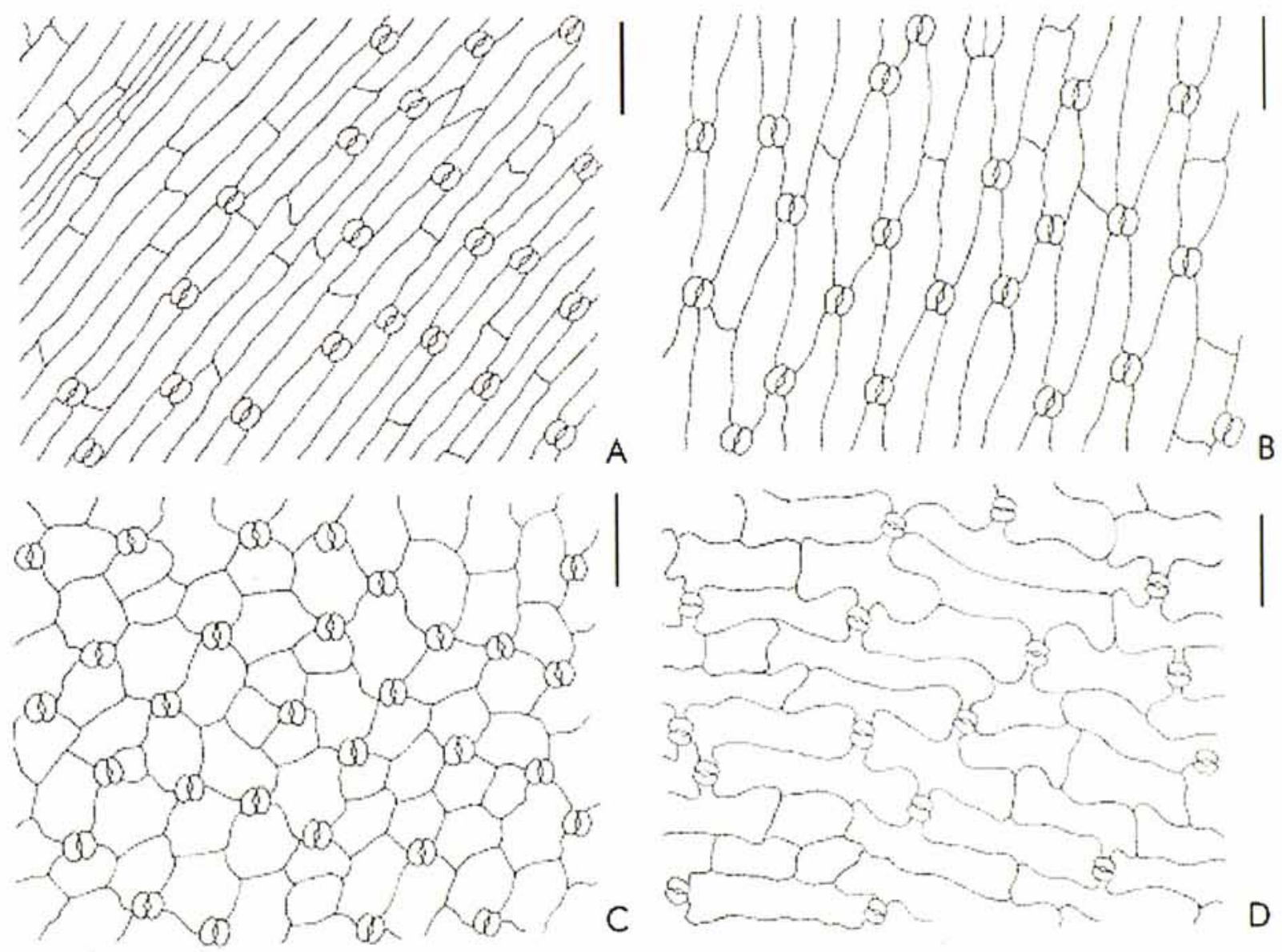

Figure 8.- Epidermic leaf cell shape. A. Rectangular cells. B. Rhomboidal cells. C. Polygonal cells. D. Rectangular cells with sinuose anticlinal walls. Black lines correspond to $100 \mu \mathrm{m}$. 
Table 3.- Micromorphological and anatomical leaf characteristics. Epidermic cells: mean \pm standard deviation $(\mu \mathrm{m})$. LAd and WAd $=$ Epidermic cell length and width in adaxial face; SAd=Epidermic cell shape in adaxial face; Lab and Wab=Epidermic cells length and width in abaxial face; $\mathrm{SAb}=$ Epidermic cell shape in abaxial face. RE=Rectangular, $\mathrm{RO}=$ Romboidal, $\mathrm{PO}=$ Polygonal. IeAd=Stomatic index in adaxial face (in \%). IeAb=Stomatic index in abaxial face (in \%). Central epidermic cells of the lamina: $\mathrm{D}=$ different size; $\mathrm{S}=$ similar size. M: Mesophyll ( $\mathrm{ND}=$ undifferentiated; $\mathrm{D}=$ differentiated). Number of layers of palisade parenchyma in parenthesis. ID= Idyoblasts ( $\mathrm{F}=\mathrm{Frequent}, \mathrm{FF}=\mathrm{Few}$ frequent). Numbers in parenthesis in 'Leaf margin' correspond to the cells forming the hairs. -: missing data.

\begin{tabular}{|c|c|c|c|c|c|}
\hline \multirow[b]{2}{*}{ Taxon } & \multirow[b]{2}{*}{ Leaf margin } & \multicolumn{4}{|c|}{ Epidermic cells } \\
\hline & & LAd & WAd & SAd & $\mathrm{LAb}$ \\
\hline $\begin{array}{l}\text { A. albanense subsp. } \\
\text { clanwilliamense }\end{array}$ & Papillose & $242.0 \pm 66.8$ & $41.5 \pm 4.2$ & $\mathrm{RE}$ & $310.5 \pm 42.4$ \\
\hline A. austrocapense & Papillose & $221.0 \pm 58.4$ & $62.0 \pm 9.9$ & RO & $289.0 \pm 69.1$ \\
\hline A. bellum & Smooth & $203.5 \pm 35.5$ & $34.5 \pm 5.4$ & $\mathrm{RE}$ & $165.5 \pm 45.8$ \\
\hline $\begin{array}{l}\text { A. burchellii subsp. } \\
\text { burchellii }\end{array}$ & Hairy (4-6) & $101.0 \pm 9.1$ & $63.5 \pm 11.4$ & $\mathrm{PO}$ & $214.0 \pm 20.2$ \\
\hline $\begin{array}{l}\text { A. burchellii subsp. } \\
\text { pulchrum }\end{array}$ & Hairy (5-9) & $70.5 \pm 12.4$ & $78.0 \pm 6.7$ & $\mathrm{PO}$ & $224.5 \pm 25.5$ \\
\hline A. capense & Hairy (8-10) & $174.0 \pm 35.8$ & $34.0 \pm 2.9$ & $\mathrm{RE}$ & $254.0 \pm 31.2$ \\
\hline A. circinatum & Smooth & $232.5 \pm 60.0$ & $27.5 \pm 3.5$ & $\mathrm{RE}$ & $240.5 \pm 45.4$ \\
\hline A. cuspidatum & Smooth & $183.5 \pm 24.9$ & $41.5 \pm 5.2$ & RE & $234.0 \pm 47.7$ \\
\hline A. dregei & Papillose & $214.5 \pm 70.1$ & $27.0 \pm 2.1$ & $\mathrm{RE}$ & $257.5 \pm 24.2$ \\
\hline A. eghimocymbion & Papillose & $285.5 \pm 42.7$ & $53.5 \pm 4.2$ & $\mathrm{RE}$ & $306.5 \pm 63.2$ \\
\hline A. hantamense & Hairy (3-5) & $178.5 \pm 30.9$ & $58.5 \pm 4.5$ & RO & $195.0 \pm 30.0$ \\
\hline A. henssenianum & Smooth & - & - & $\mathrm{RE}$ & - \\
\hline A. huntleyi & Smooth & - & - & - & - \\
\hline A. irroratum & Papillose & $218.5 \pm 50.4$ & $37.0 \pm 54$ & RO & $217.0 \pm 42.5$ \\
\hline A. poeltianum & Papillose & $242.5 \pm 45.0$ & $49.0 \pm 4.2$ & $\mathrm{RE}$ & $228.5 \pm 85.4$ \\
\hline A. villosum & Hairy (1) & $185.5 \pm 33.7$ & $34.5 \pm 2.1$ & $\mathrm{RE}$ & $198.5 \pm 41.7$ \\
\hline A. walteri & Papillose & $155.5 \pm 45.1$ & $47.5 \pm 7.7$ & RE & $157.0 \pm 19.4$ \\
\hline
\end{tabular}

the shortest to A. burchellii subsp. pulchrum (Table 3). The widest cells in the adaxial face belonged to $A$. burchellii subsp. pulchrum, and the narrowest cells to $A$. dregei. The longest cells in the abaxial face belonged to A. albanense subsp. clanwilliamense, and the shortest to A. walteri. The widest cells in the abaxial face belonged to A. hantamense, and the narrowest to A. dregei.

Androcymbium leaves are amphystomatic with anomocytic stomata (DILCHER, 1974), as in most families of the Liliales, except for the Orchidaceae and Cypripediaceae (DAHLGREN et al., 1985). The stomatic indices (STIs) ranked between 20 in A. villosum and 39.6 in A. eghimocymbion in the adaxial face, and between 18.2 in A. bellum and 40 in $A$. eghimocymbion in the abaxial face (Table 3).

\section{Leaf anatomy}

The epidermis was formed by only one quadrangular or rounded cell layer. In a transversal cut, the central epidermic cells on the adaxial face were similar in size to the rest of cells in A. austrocapense, A. cuspidatum, A. dregei and A. eghimocymbion (fig. 4H, 4J; 


\begin{tabular}{|c|c|c|c|c|c|c|}
\hline \multicolumn{4}{|c|}{ Central cells } & & \multirow[b]{2}{*}{ M } & \multirow[b]{2}{*}{ ID } \\
\hline WAb & $\mathrm{SAb}$ & IeAd & $\mathrm{IeAb}$ & & & \\
\hline $43.0 \pm 3.7$ & RE & 35.7 & 38.6 & D & ND & $\mathrm{F}$ \\
\hline $45.5 \pm 6.9$ & RO & 34.1 & 34.0 & $\mathrm{~S}$ & $\mathrm{D}(2-3)$ & $\mathrm{F}$ \\
\hline $39.0 \pm 4.5$ & $\mathrm{RE}$ & 25.4 & 18.2 & $\mathrm{~S}$ & ND & $\mathrm{FF}$ \\
\hline $52.5 \pm 3.5$ & RO & 25.7 & 24.5 & D & $\mathrm{D}(4)$ & $\mathrm{F}$ \\
\hline $53.5 \pm 3.8$ & RO-RE & 32.7 & 30.0 & D & $\mathrm{D}(2-4)$ & $\mathrm{F}$ \\
\hline $44.0 \pm 3.4$ & RE-RO & 32.9 & 32.7 & D & $\mathrm{D}(1)$ & F \\
\hline $46.5 \pm 4.2$ & RE & 29.7 & 18.6 & D & ND & $\mathrm{F}$ \\
\hline $36.5 \pm 1.4$ & RE & 27.6 & 20.7 & $\mathrm{~S}$ & ND & $\mathrm{FF}$ \\
\hline $25.5 \pm 2.1$ & RE & 25.9 & 28.9 & $\mathrm{~S}$ & $\mathrm{D}(1)$ & FF \\
\hline $55.5 \pm 5.7$ & RO & 39.6 & 40.0 & $\mathrm{~S}$ & ND & $\mathrm{F}$ \\
\hline $62.5 \pm 0.0$ & RO-PO & 36.7 & 27.7 & D & $D(5-7)$ & $\mathrm{F}$ \\
\hline - & RE & - & - & D & ND & $\mathrm{FF}$ \\
\hline - & - & - & - & D & ND & $\mathrm{F}$ \\
\hline $51.5 \pm 5.8$ & RO-PO & 36.1 & 31.6 & D & $\mathrm{D}(2-3)$ & $\mathrm{F}$ \\
\hline $34.5 \pm 5.4$ & RE & 25.5 & 18.8 & D & ND & $\mathrm{FF}$ \\
\hline $37.0 \pm 2.1$ & RE & 20.0 & 20.0 & D & ND & $\mathrm{F}$ \\
\hline $51.5 \pm 2.9$ & RE-RO & 31.1 & 28.4 & D & ND & FF \\
\hline
\end{tabular}

fig. 5A; fig. 6G). In the other species studied, the central cells were three to four times larger than the rest (fig. 4A, 4C, 4E, 4G; fig. 5C, 5E, 5G; fig. 6A, 6C, 6E, 6I, 6K).

The mesophyll was made up of 6-12 cell layers and corresponded to $60-88 \%$ of the lamina thickness. We were able to recognize two mesophyll types according to their having differentiated or undifferentiated cells (Table 3 ). The first type showed isodiametric cells forming the spongy parenchyma, and prismatic cells forming the palisade parenchyma (fig. 4). The palisade parenchyma in both faces of the lamina was observed in A. hantamense (fig. 4E). The palisade parenchyma on the adaxial face was shown in A. austrocapense, A. burchellii subsp. burchellii, A. burchellii subsp. pulchrum, A. capense, A. dregei and A. irroratum (fig. 4A, 4C, 4G, 4H, 4J). The other species showed a mesophyll with only isodiametric cells (fig. 5 and 6).

The density of leaf idioblasts (i. e., specialised cells that produce sulphurate mucopolysaccharides that are released between the parenchyma cells and are similar to these in shape and size) was variable at the intra and inter-specific levels. In general, leaf idioblasts were less frequent in A. bellum, A. cuspidatum, A. dregei, A. henssenianum, A. poeltianum and A. walteri (Table 3 ). 


\section{DISCUSSION}

The presence of a papery corm tunic could be considered a primitive trait in Androcymbium on the grounds that it is shared with other genera of the Colchicaceae like Colchicum or Ornithoglossum (NoRDENSTAM, 1982). These papery tunics have been described in the Southwestern African species A. austrocapense, that occurs along the Coast from Cape Town to Port Elizabeth, and also in species in Southeastern Africa, like A. decipiens, A. longipes and A. natalense. Following these observations, a papery texture could be associated with the different amount of rainfall in the areas where Androcymbium is distributed. Androcymbium austrocapense and the Southeastern African species inhabit a zone with abundant winter rainfall, whereas the rest of Southwestern African species studied (those which exhibit coriaceous tunics), occur in a climate characterized by high aridity.

The distichous leaf distribution with the first leaf in transversal position in the newly described species A. worsonense U. Müll.-Doblies \& D. Müll.-Doblies (MülLERDoblies \& MÚlLER-Doblies, 1998) was the diagnostic characteristic used to differentiate it from A. cuspidatum, which is described with a tristichous leaf distribution. However, we have observed both leaf distributions in the same population of $A$. cuspidatum in cultivation. In the face of this intra-population variability, the description of $A$. worsonense could be superfluous if other discriminative characteristics between these two species do not exist.

A circinate apex was observed in A. circinatum, A. villosum and A. henssenianum. The former two are closely related at the morphological (MüLlER-Doblies \& MülLERDoblies, 1998; Membrives, 2000), allozymatic (Membrives et al., 2001), and cpDNA RFLPs levels (CAUJAPÉ-CASTELlS et al., 1999). Conversely, A. henssenianum does not bear a close relation to any of these two species either morphologically or allozymatically and it is included in a different section in the new proposal of classification of the genus (Membrives, 2000). Apex morphology could therefore be considered a convergent characteristic in these species.

As opposed to the morphological homogeneity reported in their Northern African congeners (Greuter 1967; Pedrola-Monfort, 1993), Southwest African species of Androcymbium exhibit differences in leaves and bracts that have been considered taxonomically informative (BAKER, 1874; MÜlLER-Doblies \& MÜLLER-DOBLIES, 1998). Specifically, our survey distinguishes three groups of species according to the shape and color of leaves and bracts. One of them is formed by species with undifferentiated leaves and bracts (A. dregei and the Northern African species). A second group is that of species with bracts smaller and more rounded than leaves (A. albanense subsp. clanwilliamense, $A$. austrocapense, A. bellum, A. circinatum, A. cuspidatum, A. eghimocymbion, A. henssenianum, A. huntleyi, A. irroratum, A. poeltianum, A. villosum and A. walteri). Finally, a third group is formed by species with bracts and leaves different in shape and color (A. burchellii subsp. burchellii, A. burchellii subsp. pulchrum, A. capense and A. hantamense). While admitting a few exceptions, these groups show a close correspondence with the phylogenetic classification based on morphological data proposed by MEmBrives (2000). Another group according to the gradual transformation from leaves to bracts was established by MüLLERDOBLIES \& MÚLLER-Doblies (1998) to diagnose the new Subsection Gradatocymbium in their recent revision of Section Androcymbium. This trait was not included in the morphological cladistic analysis, where only leaves and bracts, differentiated and undifferentiated in shape, were considered.

The hairy indument on the leaf margins seems to follow two different trends in the four species where it was observed. The first is characterized by long and frequent hairs and 
was observed in A. hantamense and A. capense. While these two species are closely related macromorphologically, they exhibit considerable differentiation at the allozymatic level, with a genetic identity of 0.242 (Membrives et al., 2001). The second general trend features short and scattered hairs and was observed in A. burchellii subsp. burchellii, and A. burchellii subsp. pulchrum. In sharp contrast with the heterogeneity observed in the two species exhibiting the first kind of indument, these two subspecies are very closely related at all studied levels: morphological, allozymatic (MEMBRIVES et al., 2001), and cpDNA RFLPs (CAUJAPÉ-CASTELLS et al., 1999).

WILSON (1998) described rectangular, rhomboidal and polygonal epidermic cell shapes in species of the series Californicae of the genus Iris and suggested that a polygonal shape could be a consequence of the division of rhomboidal cells. If this was an explanation in Androcymbium, then the stomatic indices (STI) in species with polygonal cells should be higher than in species with rectangular or rhomboidal cells, because the relationship between the number of total cells as related to the stomatic cells should be higher. Our results are at odds with Wilson's hypothesis, since we detected no significant differences $(\mathrm{t}=0.372 ; \mathrm{p}=0.716)$ in the values of adaxial face STIs between species with polygonal cells and species with rectangular or rhomboidal cells.

The low morphological variability observed in macromorphological characteristics in the Northern African species of Androcymbium contrasts with the remarkable qualitative and quantitative heterogeneity in anatomical traits (MATEU-ANDRÉS et al., 1996). First, mesophyll cells can be subdivided into two groups depending on whether the cells are differentiated or undifferentiated. Secondly, the size of the central epidermic cells is different in relation to the rest of the cells in the lamina. Analogous variability patterns have been shown for Southwestern African species (Table 3).

Androcymbium capense and A. dregei showed only one layer of prismatic cells of palisade parenchyma. These two species are not closely related at any of the different levels at which the genus has been studied (Membrives et al., 2002; CAUJAPÉ-CASTELlS et al., 1999). The other species with differentiated mesophyll cells showed between two and four cell layers, except for $A$. hantamense, which revealed the entire mesophyll to be composed of prismatic cells (from five to seven layers). Among these species, A. burchellii subsp. burchellii, and $A$. burchellii subsp. pulchrum, shared with $A$. irroratum the ovate leaf shape and thick texture, but are not closely related in the analysis to allozymic and cpDNA RFLPs. Androcymbium austrocapense, with two or three prismatic cell layers, is not closely related to any of the other species characterized by palisade parenchyma (Table 3 ).

The idioblasts described in leaves, bracts and tepals in Androcymbium have been related to the question of defence against herbivores (MATEU-ANDRÉS et al., 1996). Similar secretive glandulae have not been reported in other genera of the Colchicaceae. Within the monocots, only the Liliaceae produce organic sulphurs (BERNHARD, 1970) and this trend has been considered taxonomically significant (SAGHIR et al., 1966). Although idioblasts can be considered an exclusive characteristic of Androcymbium, the high intra and inter-specific variability in their amount and distribution hinders the use of this quality as a species diagnostic.

On the whole, Southern African species of the genus Androcymbium show a remarkable heterogeneity in macromorphological, micromorphological and anatomical characteristics analysed. Macromorphological characteristics related to colour and shape of leaves and bracts could be used as taxonomic indicators of relationships among species in the genus. Conversely, the micromorphological and anatomical characteristics studied showed a great variability of types that does not agree with previous relationships among species according to morphological, allozymatic or cpDNA RFLPs data. 


\section{ACKNOWLEDGEMENTS}

We thank Dr. Julià Molero and Dra. Anna M. Rovira for their advice in micromorphological and anatomical methodology. Josep Maria Montserrat gave meaningful suggestions on a previous draft of the manuscript. Amparo Ardanuy provided for the welfare of the material in cultivation. The Karl Faust Foundation granted the economic support for this investigation.

\section{REFERENCES}

Arnold, T. H. \& B. C. DE WeTt (1993). Plants of southern Africa: Names and Distribution. Memoirs of the botanical survey of South Africa No. 62. Pp. 131.

BAKER, J. G. (1874). On the genus Androcymbium, with descriptions of seven new species. J. Linn. Soc. Bot., 10: 201.

BERNhARD, R. A. (1970). Chemotaxonomy: distribution studies of sulphur compounds in Allium. Phytochemistry 9: 2.019-2.027.

Caujapé-Castells, J., R. K. Jansen, J. Pedrola-Monfort \& N. Membrives (1999). Chloroplast DNA Restriction Site Phylogeny of the Genus Androcymbium (Colchicaceae). Syst. Bot. 24 (4): 581-597.

Dahlgren, R. M. T., H. T. Clifford \& P. F. Yeo (1985). The families of the Monocotyledons. Structure, Evolution, and Taxonomy. Springer-Verlag, Berlín.

DILCHER, D. L. (1974). Approaches to the identification of angiosperm leaf remains. Bot. Rev. 40: 1-157.

Greuter, W. R. (1967). Contributiones floristicae Austro-Aegeae. Candollea 22 (2): 233-253.

Heywood, V. H. (1978). Flowering Plants of the world. Oxford University Press. Oxford.

Johansen, D. A. (1970). Plant microtechnique. Mc Graw-Hill Book Co. New York.

Krause, K. (1920). Revision der Gattung Androcymbium Willd. Notizbl. Bot. Gart. Berlin-Dahlem 7:512-526.

Margelí, M., J. Pedrola-Monfort \& J. Vallès-Xirau (1998). Karyological studies in the genus Androcymbium Willd. (Colchicaceae). Austr: J. Bot. 47: 131-146.

Martín, J., J. Pedrola-Monfort \& J. Caujapé-Castells (1993). Pollen morphology and biometry in Androcymbium (Colchicaceae). Can. J. Bot. 71: 1.369-1.374.

Mateu-Andrés, I., J. Pedrola-Monfort \& J. Güemes (1996). Morfología y anatomía foliar del complejo Androcymbium gramineum (sect. Erythrostictus Benth., Colchicaceae). Candollea 51: 203-214.

Membrives, N. 2000. Biologia evolutiva del gènere Androcymbium (Colchicaceae) a Sudàfrica Occidental. Ph. Dissertation. Universitat de Barcelona, Spain.

Membrives, N., J. Pedrola-Monfort \& J. Caujapé-Castells (2001). Relative influence of biological versus historical factors on isozyme variation of the genus Androcymbium (Colchicaceae) in Africa. Plant Syst. Evol. 229: 237-260.

Membrives, N., J. Martín, J. Caujapé-Castells \& J. Pedrola-Monfort (2002). Pollen morphology and biometry of the genus Androcymbium (Colchicaceae) in southern Africa: taxonomic and biogeographic consideration. Bothalia 32 (1): 91-96.

Montserrat, J. M., N. Membrives, J. Caujapé-Castells \& J. Pedrola-Monfort (2002). Números cromosómicos de algunas especies surafricanas del género Androcymbium Willd. (Colchicaceae). Lagascalia 22 (2): 145-151.

Müller-Doblies, U. \& D. Müller-Doblies (1984). Zur Kenntnis der Gattung Androcymbium (Colchicaceae) im südlichen Afrika: Zwei Synonyma und fünf neue Arten. Willdenowia 14:179-197.

Müller-Doblies, U. \& D. Müller-Doblies (1998). De Liliifloris Notulae. 6. De decuria prima specierum novarum generis Androcymbium sect. Androcymbium (Colchicaceae) in Africa Australi s.l. Praeterea novitates de huius sectionis nonnullarum specierum distributione (praesertim aucta speciminibus Stellenbosensibus i.a. collectis a botanico vero E. G. H. Olivero). Fedd. Repert. 109, 7-8, 551-572.

NoRdEnStAM, B. (1982). A monograph of the genus Ornithoglossum (Liliaceae). Opera Botánica 64: 1-51. 
PEDROla-Monfort, J. (1993). Biologia poblacional del complexe Androcymbium gramineum (Cav.) Mc Bride secció Erythrostictus Benth. génere Androcymbium (Colchicaceae). Ph. Dissertation. Departamento de Botánica, Universidad de Valencia, Spain.

Pedrola-Monfort, J., N. Membrives, J. M. Montserrat \& J. Caujapé-Castells (1999a). A new species from the Western of South Africa: Androcymbium huntleyi (Colchicaceae). Fontqueria 53: 1-2.

Pedrola-Monfort, J., N. Membrives \& J. M. Montserrat (1999b). Two new Androcymbia (Colchicaceae) from Western South Africa. Fontqueria 54 (2): 7-9.

Pedrola-Monfort, J., N. Membrives, J. M. Montserrat \& J. Caujapé-Castells (2002). Systematic relationships of some species of the genus Androcymbium Willd. (Colchicaceae) in western South Africa. Botánica Macaronésica 24. (in press.)

SAGHIR, A. R., L. K. MANN, M. OWNBEy \& R. Y. BERG (1966). Composition of volatiles in relation to taxonomy of American Alliums. Amer. J. Bot. 53: 477-484.

WiLSON, C. A. (1998). A cladistic analysis of Iris series Californicae based on morphological data. Syst. Bot. 23 (1): 73-88. 